\title{
Stilbenes from Deguelia rufescens var. urucu (Ducke) A. M. G. Azevedo Leaves: Effects on Seed Germination and Plant Growth
}

\author{
Lívia T. Lobo, ${ }^{a}$ Geilson A. da Silva, ${ }^{a}$ Manolo C. C. de Freitas, ${ }^{a}$ Antonio Pedro S. Souza Filho, ${ }^{b}$ \\ Milton N. da Silva, ${ }^{a}$ Alberto C. Arruda, ${ }^{a}$ Giselle M. S. P. Guilhon, ${ }^{a}$ Lourivaldo S. Santos, ${ }^{a}$ \\ Alberdan S. Santos ${ }^{a}$ and Mara S. P. Arruda*,a \\ ${ }^{a}$ Programa de Pós-Graduação em Química, Instituto de Ciências Exatas e Naturais, Universidade \\ Federal do Pará, Rua Augusto Corrêa 01, Guamá, 66075-970 Belém-PA, Brazil \\ ${ }^{b}$ Centro de Pesquisa Agroflorestal da Amazônia Oriental-CPATU, \\ CP 48, 66095-100 Belém-PA, Brazil
}

\begin{abstract}
A biodiversidade Amazônica pode ser uma fonte de substâncias capazes de serem utilizadas no controle de plantas daninhas. Neste estudo relatamos o isolamento e a identificação de cinco estilbenos a partir das folhas do "timbó vermelho" (Deguelia rufescens var. urucu): 4-metoxilonchocarpeno (1); 3,5-dimetoxi-4'-hidroxi-3'-prenil-trans-estilbeno (2), lonchocarpeno (3), 3,5-dimetoxi-4'-O-prenil-trans-estilbeno (4) e pteroestilbeno (5). As substâncias 2 e 4 são novos produtos naturais, porém $\mathbf{2}$ já havia sido citada como produto de síntese. Foi avaliada a potencial atividade alelopática de 1, 2 e $\mathbf{4}$ sobre a germinação de sementes e o crescimento da planta daninha Mimosa pudica. Os efeitos observados sobre a germinação das sementes de $M$. pudica não variaram significantemente $(\mathrm{p}>0,05)$ quando a análise da fitotoxidade foi realizada com as substâncias isoladamente, cuja inibição máxima não ultrapassou 20\%. A inibição mais intensa, quanto ao desenvolvimento da radícula e do hipocótilo, foi encontrada para o composto 4 ( $p<0,05)$. Isoladamente, 4 causou efeito inibitório significativamente maior $(\mathrm{p}<0,05)$ no desenvolvimento da radícula e do hipocótilo, do que $\mathbf{1}$ e $\mathbf{2}$. Quando testados aos pares, apresentaram antagonismo para a germinação de sementes e sinergismo para o desenvolvimento da radícula e hipocótilo.
\end{abstract}

The Amazon biodiversity may provide plants whose chemical substances are capable of controlling weeds. In this study we report the isolation and identification of five stilbenes from the leaves of "timbó vermelho" (Deguelia rufescens var. urucu): 4-methoxylonchocarpene (1); 3,5-dimethoxy-4'-hydroxy-3'-prenyl-trans-stilbene (2), lonchocarpene (3), 3,5-dimethoxy-4'-Oprenyl-trans-stilbene (4) and pterostilbene (5). Compounds $\mathbf{2}$ and $\mathbf{4}$ are new natural products although $\mathbf{2}$ has been previously cited as synthesis product. Potential allelopathic activity for 1, 2 and $\mathbf{4}$ was evaluated over seed germination and plant growth of Mimosa pudica weed. The observed effects on seed germination did not vary significantly $(\mathrm{p}>0.05)$ when the analysis of phytotoxicity was performed with the substances alone, the maximum inhibition did not exceed $20 \%$. The most intense inhibitions on radicle and hypocotyl development were found for compound 4 ( $p<0.05$ ). When tested in pairs, showed antagonism for seed germination and synergism for radicle and hypocotyl development.

Keywords: Deguelia rufescens var. urucu, stilbenes, allelopathy, allelochemicals, phytotoxicity, germination and growth inhibitions

\section{Introduction}

The Amazon Forest, due its biological wealthy and diversity of species, offers an opportunity to find

*e-mail: mspa@ufpa.br innovative and efficient molecules able to be used in the most varied agricultural activities, both in the handling of agricultural pests of economic importance and in weed control. Such aspects have resulted in several studies during the last few years, using native plants to isolate, identify and detect allelopathic activity. In the course of 
those studies, emphasis should be given to the investigation with Myrcia guianensis, ${ }^{1}$ Parkia pendula,${ }^{2}$ Tachigali myrmecophila, ${ }^{3}$ Piper hispidinervium, ${ }^{4}$ Virola michelli ${ }^{5}$ and Cyperus giganteus, ${ }^{6}$ which allow identification of potent allelochemicals.

Among the various species of native plants from the Amazon Forest, capable of providing molecules with possible use in agriculture are those from Deguelia (Derris/ Lonchocarpus) genera, known for their popular name of "timbó". They are vines, which grow using other tree crowns, and have long been used by native Indians for fishing. Twenty-two species of timbó have been catalogued all over the world. In the Amazon the most known species are "timbó vermelho" [Deguelia rufescens var. иrucu (Lonchocarpus urucu/Derris urucu)] and "timbó branco" [Deguelia utilis (Derris nicou/Lonchocarpus utilis)], ${ }^{7}$ whose roots are a significant source of rotenoids. ${ }^{8}$ The fact that these species display pesticide activities allowed their use as defensives in aquaculture. ${ }^{9-11}$

Although many Deguelia species have been the subject of phytochemical studies, little is known about the chemical constituents from the leaves of D. rufescens var. игиси. In a previous paper we reported the presence of dihydroflavonoids ${ }^{12}$ and we have further raised the hypothesis that leaves of this species may provide substances for use in weed control handling. Thus, the aim of this research was to evaluate the allelopathic activity of leaf constituents of D. rufescens var. urucu.

\section{Experimental}

\section{General}

UV spectra were obtained from LC equipped with DAD Prominence 20A Shimadzu. NMR spectra, including 1H-1H COSY, HETCOR, HMBC experiments, were recorded on a Varian Mercury-300 spectrometer, operating at $300 \mathrm{MHz}$ at ${ }^{1} \mathrm{H}$ and $75 \mathrm{MHz}$ at ${ }^{13} \mathrm{C}$, using $d$-chloroform as solvent and internal standard. Mass spectral analyses were performed at low resolution on a Quattro-LC instrument (Micromass, Manchester, UK) provided with an ESI ion source and a triple quadrupole mass analyzer. High resolution analyses was performed on UltrOTOF-Q (Brucker, Daltonics Billerica MA, USA) at the cationiozed ion region. The heated capillary and voltage were maintained at $250{ }^{\circ} \mathrm{C}$ and $3 \mathrm{kV}$, respectively. A $20 \mathrm{~V}$ cone energy for ion extraction and mass spectrometry data were acquired at positive mode for all compounds. HPLC was carried out in a preparative LC-8A Shimadzu system with SPD-10AV Shimadzu UV detector (Tokyo, Japan); using a Phenomenex Gemini C18 column $(250 \times 10 \mathrm{~mm}, 5 \mu)$, an isocratic system of water:acetonitrile (30:70) and a flow rate of $4.7 \mathrm{~mL} \mathrm{~min}^{-1}$. Detection was performed at 270 and $320 \mathrm{~nm}$. All solvents were filtered through a $0.45 \mu \mathrm{m}$ membrane filter prior to analysis. Absorbance measurements were recorded on a Spectrum UV SP- $220^{\circledR}$ spectrophotometer.

\section{Plant material}

Approximately $2.0 \mathrm{~kg}$ of green leaves from Deguelia rufescens var. urucu (Ducke) A. M. G. Azevedo - as synonymous Lonchocarpus urucu Killip \& A. C. Smith and Derris urucu (Killip \& A. C. Smith) J. F. Macbr. - were collected at Campo Experimental da Embrapa Amazônia Oriental, located in Belém, state of Pará, Brazil, when the plants were flowering. A fertile sample was obtained and stored at the Botanical Laboratory and a voucher was registered (IAN-179599).

\section{Extraction and isolation}

$700 \mathrm{~g}$ of dried and powdered leaves of $D$. rufescens var. игиси were extracted with ethanol at room temperature. The solvent was removed under vacuum furnishing a residue $(50 \mathrm{~g})$. The crude ethanol residue $(30 \mathrm{~g})$ was filtered on silica gel column chromatography with gradient elution of hexane:ethyl acetate (9:1, 7:3, 5:5 and 0:10) and ethyl acetate:methanol (5:5 and $0: 10)$, yielding six fractions named DU-1 (1.28 g), DU-2 (2.37 g), DU-3 (5.17 g), DU-4 $(5.36 \mathrm{~g})$, DU-5 (3.53 g) and DU-6 (3.75 g), respectively. Fraction DU-2 ( $0.5 \mathrm{~g})$ was purified by semi-preparative HPLC yielding compounds $\mathbf{1}$ (43 mg), 2 (7 mg), 3 (90 mg), $4(21 \mathrm{mg})$ and $\mathbf{5}(3 \mathrm{mg})$ which showed chromatographic peaks with retention times 10.13, 11.80, 14.91, 21.08 and $23.96 \mathrm{~min}$, respectively.

\section{Bioassays analysis of allelopathic activity}

The germination bioassay was developed in a controlled temperature chamber $25{ }^{\circ} \mathrm{C}$ for $12 \mathrm{~h}$ of photoperiod. Germination was monitored for ten days, with daily counting and elimination of germinated seeds. Germinated seeds were considered those with $2.0 \mathrm{~cm}$ or more in length of radicle. Each Petri dish (9.0 cm diameter) was covered with qualitative filter paper received 25 seeds.

Bioassays for radicle and hypocotyl development were developed similar to those of seed germination, differing only in the photoperiod which was $24 \mathrm{~h}$. Each Petri dish, covered with qualitative filter paper received three pre-germinated seeds, with approximately two days of germination. After a ten days period of growth, the root and hypocotyl were measured for their lengths. 
The substances were tested separately and in pairs, in a single $150 \mathrm{mg} \mathrm{L}^{-1}$ concentration. Each Petri dish received $3.0 \mathrm{~mL}$ of solution test. Specifically for bioassays of substances tested in pairs, it was used $50 \%$ of the volume for each substance. After the eluent evaporation, an equivalent volume of distilled water was added, to maintain the original concentration. The solutions were added just once, at the beginning of the tests, after that only distilled water was added whenever necessary.

The plant used as an indicator of allelopathic effects was the specie malícia (Mimosa pudica) weed. The seeds of the specie were collected in pasture fields in the municipality of Terra Alta, Pará State; they went through the cleaning process and were treated to break the dormancy by immersion in sulphuric acid for $20 \mathrm{~min}$, as specified by Souza Filho et al. ${ }^{13}$

\section{Experimental design and statistical data analysis}

A completely randomized design was used for all bioassays, with four replications, using distilled water as control treatment. The data were transformed to arc sine $\sqrt{x}$, to follow normal distribution. The values obtained were submitted to variance analysis, using F-test, and when the treatment effects presented significant differences $(p<0.05)$ and the means were compared using the Tukey test. Computer program statistical analysis system (SAS) was used in analysis. ${ }^{14}$

\section{3,5-Dimethoxy-4'-hidroxy-3'-prenyl-trans-stilbene (4)}

Yellow crystals; IR $v_{\max } \mathrm{cm}^{-1} 2916,1584,1556$, $1509,1454,1146,1063,957,824$ (thin solid film); UV $\lambda_{\max } / \mathrm{nm}$ (water/acetonitrile) $215,235,305,317$; HRESIMS (positive mode) [M+Na] $]^{+}$Found: 347.1657. Calc. for $\mathrm{C}_{21} \mathrm{H}_{24} \mathrm{O}_{3} \mathrm{Na}$ : 347.1623; ESIMS: 347, $325[\mathrm{M}+\mathrm{H}]^{+}$, $284\left[\mathrm{M}+\mathrm{H}-41\left(\mathrm{C}_{3} \mathrm{H}_{5}\right)\right]^{+} ;{ }^{1} \mathrm{H}$ and ${ }^{13} \mathrm{C}$ NMR spectral data: see Tables 1 and 2.

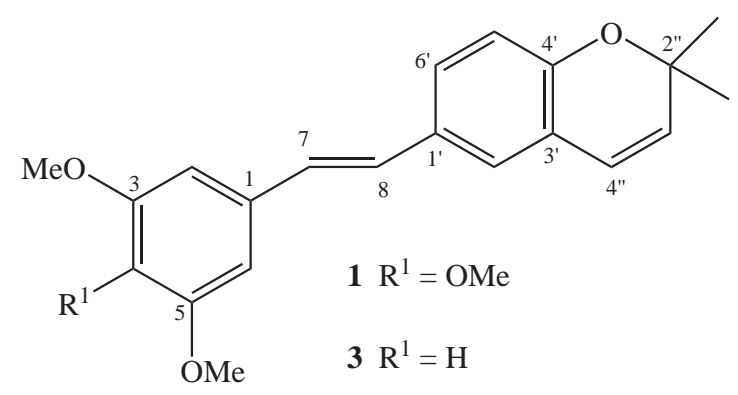

\section{Results and Discussion}

\section{Phytochemical investigation}

Chromatography column followed by semi-preparative HPLC of the ethanolic extract of $D$. rufescens leaves, led to the isolation of compounds 1-5 (Figure 1). Compounds $\mathbf{1}$, $\mathbf{2}, \mathbf{3}$, and $\mathbf{5}$ were identified as 4-methoxylonchocarpene, ${ }^{15}$ 3,5-dimethoxy-4'-hydroxy-3'-prenyl-trans-stilbene, lonchocarpene ${ }^{16}$ and pterostilbene, ${ }^{17}$ respectively, by comparison of their spectral data with those reported in literature.

Compound 4 was obtained as a pale yellow amorphous solid. The HRESIMS displayed a pseudomolecular ion $[\mathrm{M}+\mathrm{Na}]^{+}$at $\mathrm{m} / \mathrm{z}$ 347.1657, consistent with the molecular formula $\mathrm{C}_{21} \mathrm{H}_{24} \mathrm{O}_{3} \mathrm{Na}$ (calc. for $\mathrm{C}_{21} \mathrm{H}_{24} \mathrm{O}_{3} \mathrm{Na}, 347.1623$ ), which was further corroborated by the NMR data. The $\delta$ 6.0-7.5 ppm region of the ${ }^{1} \mathrm{H}$ NMR spectrum of 4 (Table 1) showed resonances for two pairs of equivalent orthoaromatic protons from one 1,4-disubstituted phenyl ring, at $\delta 6.91$ and $7.44(\mathrm{~d}, J 8.7 \mathrm{~Hz}, 2 \mathrm{H}$ each), three meta-coupled aromatic protons at $\delta 6.38(d, J 2.1 \mathrm{~Hz}, 1 \mathrm{H})$ and $6.65(\mathrm{~d}$, $J 2.1 \mathrm{~Hz}, 2 \mathrm{H}$ ) from one 1,3,5-trisubstituted phenyl ring, as well as a pair of trans-olefinic protons, at $\delta 6.91$ and 7.15 (d, $J 16.0 \mathrm{~Hz}, 1 \mathrm{H}$ each), typical of a trans-stilbene. ${ }^{16} \mathrm{In}$ addition, was observed a six-proton singlet at $\delta 3.83 \mathrm{ppm}$ due to two magnetically equivalent OMe groups, and signals due to a $O$-prenyl group $[\delta 4.53(\mathrm{~d}, J 6.9 \mathrm{~Hz}$, $2 \mathrm{H}), 5.51(\mathrm{t}, J 6.9 \mathrm{~Hz}, 1 \mathrm{H}), 1.76$ and 1.81 (s, 3H each)]. The ${ }^{13} \mathrm{C}$ NMR, HSQC and DEPT spectra of 4 (Table 1) displayed 16 signals assignable to 21 carbons of a stilbene containing a prenyloxy group and two methoxy groups, thus revealing the presence of five pairs of equivalent carbons. The chemicals shifts for H-7 and H-8 at $\delta 6.91$ and $7.05 \mathrm{ppm}$, respectively, were confirmed on the basis of the HMBC correlations of H-7 with C-2/6 ( $\delta 104.3$ ppm) and $\mathrm{H}-8$ with $\mathrm{C}-2^{\prime} / 6^{\prime}$ (Figure 2). Moreover, the long-range correlation between $\mathrm{H}-3^{\prime} / 5^{\prime}(\delta 6.90 \mathrm{ppm})$ and the signal at

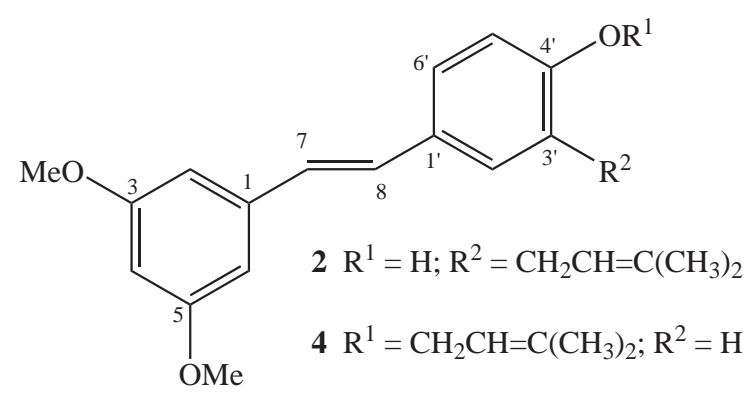

$5 \mathrm{R}^{1}=\mathrm{R}^{2}=\mathrm{H}$

Figure 1. Chemical structure of stilbenes 1-5, isolated from Deguelia rufescens var. иrucu leaves. 


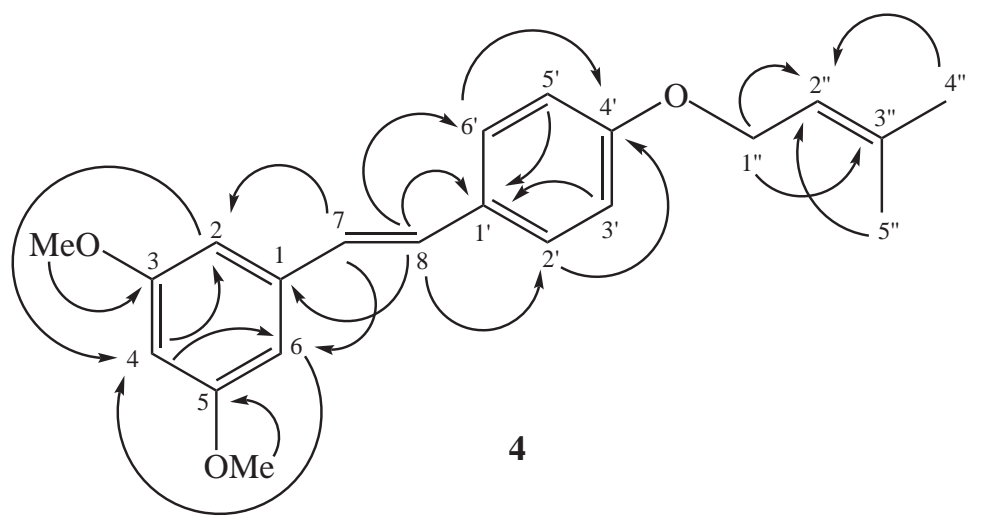

Figure 2. Key HMBC $(\mathrm{H} \rightarrow \mathrm{C})$ correlations of compound 4 .

$\delta 129.8$ ppm confirmed the $\mathrm{C}-1^{\prime}$ attribution. Correlations were also observed between $\mathrm{H}-8$ and carbons signals at $\delta 129.8\left(\mathrm{C}-1^{\prime}\right)$ and $139.7 \mathrm{ppm}$, than the signal at $\delta 139.7 \mathrm{ppm}$ that was attributed to $\mathrm{C}-1$. Compound $\mathbf{4}$ was then elucidated as $(E)$-3,5-dimethoxy-4'-O-prenylstilbene.

The occurrence of the $3^{\prime}$ - $O$-prenylstilbene analogue 2 as a natural product and its ${ }^{13} \mathrm{C}$ NMR data (Table1) are here reported for the first time. Compound $\mathbf{2}$ was previously characterized as a synthesis product. ${ }^{18}$

Table 1. ${ }^{1} \mathrm{H}$ and ${ }^{13} \mathrm{C}$ NMR chemical shift ( $\delta$ in ppm) assignments for compounds 2 e 4 in $\mathrm{CDCl}_{3}{ }^{\mathrm{a}}$

\begin{tabular}{|c|c|c|c|c|}
\hline \multirow[t]{2}{*}{ Position } & \multicolumn{2}{|c|}{2} & \multicolumn{2}{|c|}{4} \\
\hline & $\delta_{\mathrm{H}}$ & $\delta_{\mathrm{C}}$ & $\delta_{\mathrm{H}}$ & $\delta_{\mathrm{C}}$ \\
\hline 1 & & 140.9 & & 139.7 \\
\hline $2 / 6$ & $6.72(\mathrm{~d}, 2.4)^{\mathrm{b}}$ & 104.8 & $6.65(\mathrm{~d}, 2.1)$ & 104.3 \\
\hline $3 / 5$ & & 162.0 & & 160,9 \\
\hline 4 & $6.36(t, 2.4)$ & 100.0 & $6.38(\mathrm{t}, 2.1)$ & 99.5 \\
\hline 7 & $6.95(\mathrm{~d}, 16.3)$ & 126.2 & $6.91(\mathrm{~d}, 16.0)$ & 126.4 \\
\hline 8 & $7.15(\mathrm{~d}, 16.3)$ & 130.0 & $7.15(\mathrm{~d}, 16.0)$ & 128.8 \\
\hline $1^{\prime}$ & & 129.8 & & 129.8 \\
\hline $2^{\prime}$ & $7.32(\mathrm{~d}, 1.8)$ & 128.9 & $7.44(\mathrm{~d}, 8.7)$ & 127.7 \\
\hline $3^{\prime}$ & & 129.0 & $6.90(\mathrm{~d}, 8.7)$ & 114.8 \\
\hline $4^{\prime}$ & & 155.9 & & 158.6 \\
\hline $5^{\prime}$ & $6.84(\mathrm{~d}, 8.1)$ & 115.9 & $6.90(\mathrm{~d}, 8.7)$ & 114.8 \\
\hline $6^{\prime}$ & $\begin{array}{c}7.26 \\
(\mathrm{dd}, 8.1,1.8)\end{array}$ & 126.1 & $7.44(\mathrm{~d}, 8.7)$ & 127.7 \\
\hline $1^{\prime \prime}$ & $3.33(\mathrm{~d}, 7.5)$ & 29.0 & $4.53(\mathrm{~d}, 6.9)$ & 64.7 \\
\hline $2^{\prime \prime}$ & $5.34(\mathrm{t}, 7.5)$ & 123.7 & $5.51(\mathrm{t}, 6.9)$ & 119.5 \\
\hline $3^{\prime \prime}$ & & 132.4 & & 138.3 \\
\hline $\mathrm{Me}-4^{\prime \prime}$ & $1.72(\mathrm{~s})$ & 25.8 & $1.81(\mathrm{~s})$ & 25.8 \\
\hline $\mathrm{Me}-5^{\prime \prime}$ & $1.73(\mathrm{~s})$ & 17.8 & $1.76(\mathrm{~s})$ & 18.2 \\
\hline $2 \times \mathrm{OMe}$ & $3.80(\mathrm{~s})$ & 55.5 & $3.83(\mathrm{~s})$ & 55.3 \\
\hline
\end{tabular}

a Spectra were recorded at $300 \mathrm{MHz}$ for ${ }^{1} \mathrm{H}$ NMR and $75 \mathrm{MHz}$ for ${ }^{13} \mathrm{C}$ NMR. ${ }^{\mathrm{b}}$ Multiplicity and coupling constant $(J, \mathrm{~Hz})$ are in parenthesis.
Phytotoxicity of ethanolic extract and purified compounds

The effects of ethanolic extract over germination and the development of the weed malícia are showed in Figure 3. Inhibiting effects above $50 \%$ were observed with maximum verified on the hypocotyl development (58\%). The effects promoted by $\mathbf{1}, \mathbf{2}$ and $\mathbf{4}$, over seed germination (Figure 4), did not vary significantly $(\mathrm{p}<0.05)$ when the substances were considered separately. For $\mathbf{1}, \mathbf{2}$ and $\mathbf{4}$ the intensity of inhibitions on seed germination did not exceed $20 \%$ however; it was slightly higher for $\mathbf{2}$. Lower inhibiting effects were observed when pairs $\mathbf{1}+\mathbf{2}$ and $\mathbf{2}+\mathbf{4}$ were tested, indicating antagonistic effects. Comparisons between 1, 4 and $1+4$ did not show significant differences $(p>0.05)$, although slight superiority in the intensity of effects is observed in the mixture test.

Effects over radicle development of 1,2 and $\mathbf{4}$ separated and combined in pairs are showed in Figure 5. Separately $\mathbf{1}$ and $\mathbf{2}$ presented inhibitory activity below $10 \%$, without any significant difference $(\mathrm{p}>0.05)$ between them. From the three stilbenes tested, 4 presented the highest inhibitory

\section{Ethanolic Extract of Leaves}

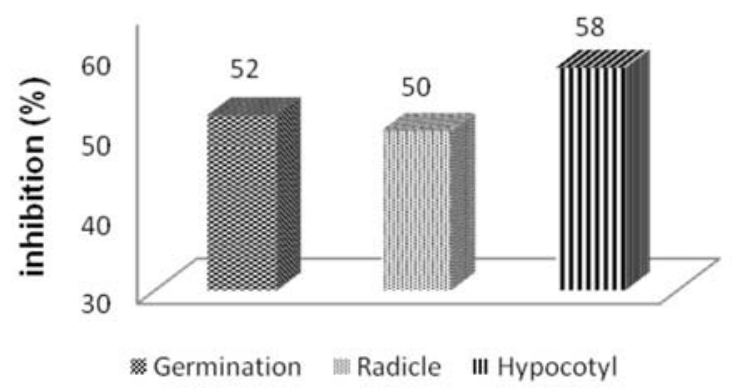

Figure 3. Effects of ethanolic extract from Deguelia rufescens var. urucu leaves over germination and development malícia weed seedling. Data is shown in percentages of inhibition in relation to control treatment, distilled water. 

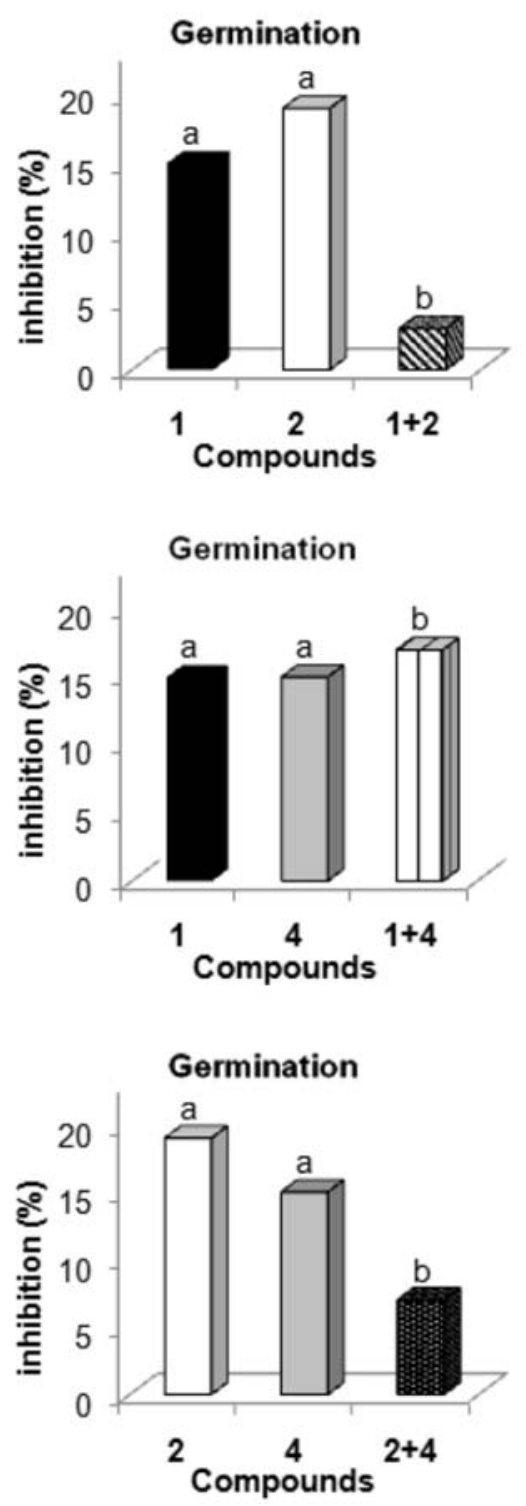

Figure 4. Allelopathic effect of stilbenes 1, 2 and 4, separately, and in pairs, over seed germination of malícia weed seedling. Data is shown in percentages of inhibition in relation to control treatment; distilled water. Letters show significant differences by the Tukey test (5\%).

activity, around 30\%, significantly higher $(\mathrm{p}<0.05)$ than $\mathbf{1}$ and $\mathbf{2}$. The standard response to the different combinations, two by two, between the three compounds, was completely different from that observed on seeds germination. The inhibitory effects promoted by $\mathbf{1 + 2}$ and $\mathbf{2 + 4}$ were significantly higher $(\mathrm{p}<0.05)$ than those of the separate substances. For $\mathbf{1}+\mathbf{2}$ the effect was four times larger than for the compounds separately, while for $\mathbf{2}+\mathbf{4}$ was 2.5 times higher. On both cases synergism was observed, contrasting with the results for seed germination.

Unlike other results on the effects promoted on the radicle development, $\mathbf{1}+\mathbf{4}$ was significantly equal $(p>0.05)$ to $\mathbf{4}$, although, quantitatively, $\mathbf{4}$ presented a higher inhibiting
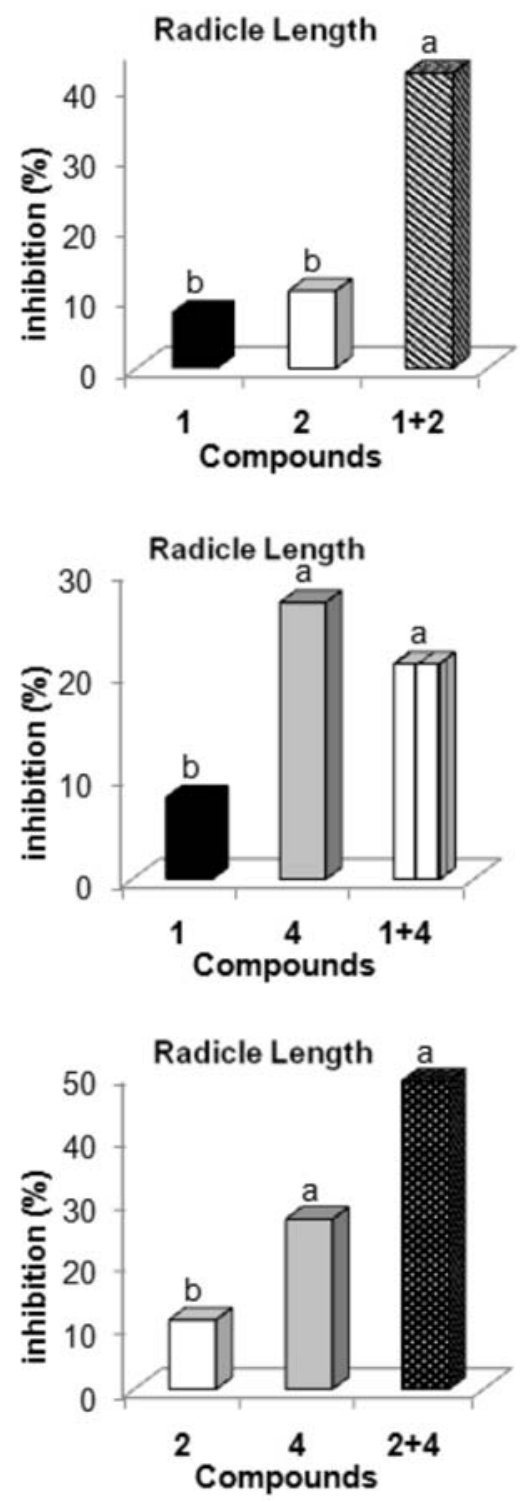

Figure 5. Allelopathic effect of stilbenes 1, 2 e 4, separately, and in pairs, over root development of malícia weed seedling. Data is shown in percentages of inhibition in relation to control treatment; distilled water. Letters show significant differences by the Tukey test $(5 \%)$.

power. Both $\mathbf{4}$ and $\mathbf{1}+\mathbf{4}$ showed inhibitory effects $(\mathrm{p}<0.05)$ larger than $\mathbf{1}$.

Compounds 1 and $\mathbf{2}$ separately, presented the lowest potential for inhibitory of hypocotyl development (Figure 6), below 10\%. Compound 4 showed strongest activity, being significantly higher $(\mathrm{p}<0.05)$ than $\mathbf{1}$ and 2. For pairs of the three compounds, the inhibitory effects were more intense $(p<0.05)$ than those caused by the single substances, indicating synergic effect.

Considering the effects promoted for the three allelochemicals over germination and root and hypocotyl development, $\mathbf{1}$ and $\mathbf{2}$ were most powerful for inhibiting seed germination. Substance $\mathbf{4}$ presented the greatest 

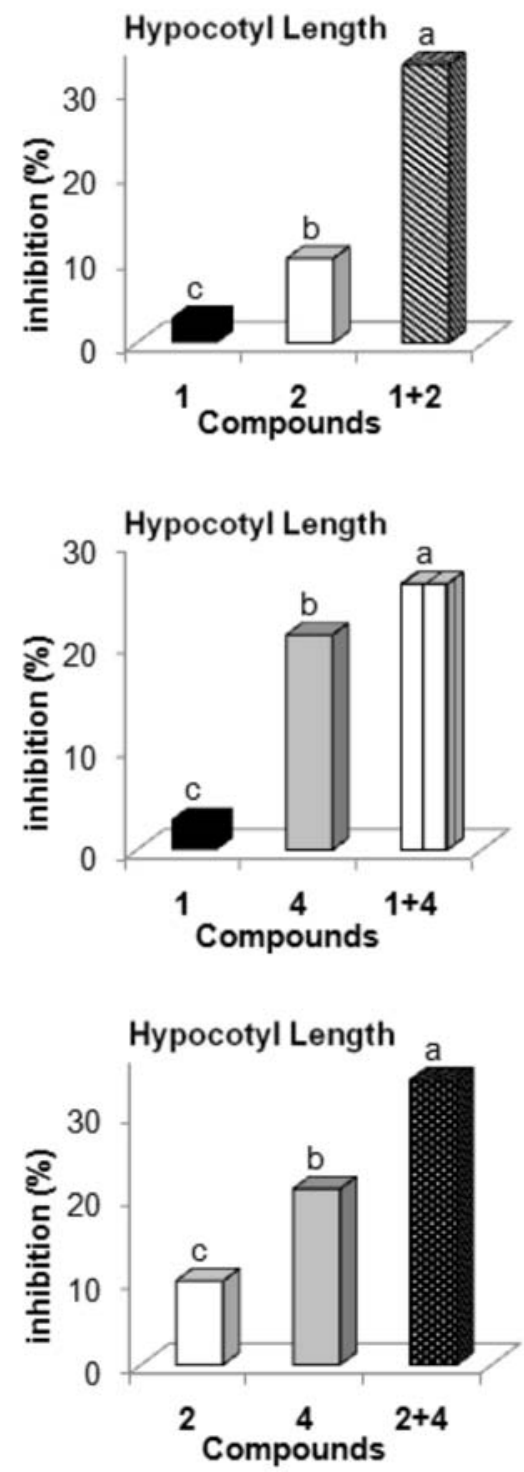

Figure 6. Allelopathic effect of stilbenes 1, 2 e 4, separately, and in pairs, over the hypocotyl development of malícia weed seedling. Data is shown in percentages of inhibition in relation to control treatment; distilled water. Letters show significant differences by the Tukey test (5\%).

inhibiting potential for roots and hypocotyl development of malícia weeds. The activity of the substances, when tested in pairs, tended to present antagonism for seed germination and synergism for seedling development.

Different biological activities were determined for stilbenes, among others antibiotics, antioxidant, bactericide, algicide, insect and growth regulatory activity. ${ }^{19-24}$ Small differences in the chemical structure of certain substances may be favorable for an increase in allelopathic activity. ${ }^{25}$ Compounds $\mathbf{1}$ and $\mathbf{2}$ showed more structural similarities to each other when compared to 4 . Those variations were not sufficient to promote differences in the inhibiting activity of seed germination. When the effects on root and hypocotyl development were analyzed, $\mathbf{1}$ and $\mathbf{2}$ did not differ much for inhibiting capacity, however $\mathbf{4}$ displayed more magnitude of inhibition.

Phenolic compounds represents the majority of the allelopathic agents identified. ${ }^{26,27}$ In plant, the effects attributed to allelopathy phenomenon resulting of compounds that are produced and released into the environment. Thus, the activity of a mixture of allelochemicals is determined by its concentration and by positive or negative interaction between these chemical constituents. The combination of allelochemicals involves fixed concentrations and inferences are based on increased activity in relation to the effects promoted by substance alone, which concludes that there is synergy, and the reduction of activity (antagonism). In our study, we observed both effects among the three substances tested. The bioassay of germination, the trend was the occurrence of antagonism, while in the radicle and hypocotyl developments, synergisms. The manifestation of synergism or antagonism apparently is not only dependent on the ability of the substances tested have to enhance the activity of another, but also of the target to be analyzed.

All the results allow us to confirm plant species from Amazon rainforest as alternative sources of molecules with properties for use in weed management, adding value to these species and contributing to Amazon rainforest preservation.

\section{Supplementary Information}

Supplementary data are available free of charge at http://jbcs.sbq.org.br, as PDF file.

\section{Acknowledgment}

We are grateful to FAPESPA (Fundação de Amparo à Pesquisa do Estado do Pará, Brazil) for financial support and we thanks to CNPq for a grant. We acknowledge Prof. Norberto Peporine Lopes for HRMS measurements.

\section{References}

1. Souza Filho, A. P. S.; Santos, R. A.; Santos, L. S.; Guilhon, G. M. P.; Santos, A. S.; Arruda, M. S. P.; Müller, A. H.; Arruda, A. C.; Planta Daninha 2006, 24, 649.

2. Souza Filho, A. P. S.; Fonseca, M. L.; Arruda, M. S. P.; Planta Daninha 2005, 23, 565.

3. Lôbo, L. T.; Castro, K. C. F.; Arruda, M. S. P.; Silva, M. N.; Arruda, A. C.; Müller, A. H.; Guilhon, G. M. P.; Santos, A. S.; Souza Filho, A. P. S.; Quim. Nova 2008, 31, 493.

4. Souza Filho, A. P. S.; Vasconcelos, M. A. M.; Zoghbi, M. G. B.; Cunha, R. L.; Acta Amaz. 2009, 39, 389. 
5. Santos, L. S.; Borges, F. C.; Oliveira, M. N.; Ferreira, I. C. S.; Guilhon, G. M. P.; Souza Filho, A. P. S.; Santos, A. S.; Arruda, M. S. P.; Müller, A. H; Arruda, A. C.; Allelopathy J. 2007, 20, 235.

6. Vilhena, K. S. S.; Guilhon, G. M. P.; Souza Filho, A. P. S.; Zoghbi, M. G. B.; Santos, L. S.; Arruda, M. S. P.; Arruda, A. C.; Allelopathy J. 2009, 23, 221.

7. Da Conceição, H. E. O.; Pinto, J. E. B. P.; De Santiago, E. J. A.; Gonçalves, A. A. S.; Ciênc. Agrotec. 2002, 26, 472.

8. Mascaro, U. C. P.; Rodrigues, L. A.; Bastos, J. K.; Santos, E.; da Costa, J. P. C.; Pesq. Vet. Bras. 1998, 18, 53.

9. Hien, P .P.; Gortnizka, H.; Kraemer, R.; Omonrice 2003, 11, 83.

10. Howard, R. K.; Environ. Biol. Fishes 1988, 24, 93.

11. Scarnecchia, D. L.; J. Iowa Acad. Sci. 1988, 95, 55.

12. Lôbo, L. T.; da Silva, G. A.; Ferreira, M.; da Silva, M. N.; Santos, A. S.; Arruda, A. C.; Guilhon, G. M. P.; Santos, L. S.; Borges, R. S.; Arruda, M. S. P.; J. Braz. Chem. Soc. 2009, $20,1082$.

13. Souza Filho, A. P. S.; Dutra, S.; Silva, M. A. M. M.; Planta Daninha 1998, 25, 3.

14. Statistical Analysis System. SAS Procedures Guide. Version 6, $3^{\text {rd }}$ ed., Statistical Analysis System Institute: Cary, NC, 1990.

15. Fang, N.; Casida, J. E.; J. Nat. Prod. 1999, 62, 205.

16. Kaouadji, M.; Agban, A.; Mariotte, A. M.; Tissut, M.; J. Nat. Prod. 1986, 49, 281.
17. Fuendjiepa, V.; Wandji, J.; Tillequinc, F.; Mulhollandd, D. A.; Budzikiewicze, H.; Fomumb, Z. T.; Nyembab, A. M.; Koch, M.; Phytochemistry 2002, 60, 803.

18. Li, Y. Q.; Song, Q. L.; Chen, P.; Zhao, W.; Wang, S.; Chem. Res. Chin. Univ. 2006, 22, 742.

19. Kato, E.; Tokunaga, Y.; Sakan, F.; J. Agric. Food Chem. 2009, $57,2544$.

20. Mizuno, C. S.; Schrader, K. K.; Rimando, A. M.; J. Agric. Food Chem. 2008, 56, 9140.

21. Lin, L. G.; Yang, X. Z.; Tang, C. P.; Phytochemistry 2008, 69, 457.

22. Lee, J. P.; Min, B. S.; Na, R. B.; Phytochemistry 2003, 64, 759.

23. Torres, P.; Avila, J. G.; Rorno, V. A.; Phytochemistry 2003, 64, 463.

24. Taylor, R. J.; Shaw, D. C.; Can. J. Bot. 1983, 61, 279.

25. Souza Filho, A. P. S.; Borges, F. C.; Santos, L. S.; Planta Daninha 2006, 24, 205.

26. Rice, E. L.; Allelopathy, Academic Press: New York, 1984.

27. Xuan, T. D.; Tsuzuki, E.; Terao, H.; Matsui, M.; Khanh, T. D.; Plant Prod. Sci. 2003, 6, 165.

Submitted: January 22, 2010

Published online: June 18, 2010 


\section{Stilbenes from Deguelia rufescens var. urucu (Ducke) A. M. G. Azevedo Leaves: Effects on Seed Germination and Plant Growth}

Livia T. Lobo, ${ }^{a}$ Geilson A. da Silva, ${ }^{a}$ Manolo C. C. de Freitas, ${ }^{a}$ Antonio Pedro S. Souza Filho, ${ }^{b}$ Milton N. da Silva, ${ }^{a}$ Alberto C. Arruda, ${ }^{a}$ Giselle M. S. P. Guilhon, ${ }^{a}$ Lourivaldo S. Santos, ${ }^{a}$ Alberdan S. Santos ${ }^{a}$ and Mara S. P. Arruda ${ }^{a *}$

${ }^{a}$ Programa de Pós-Graduação em Química, Instituto de Ciências Exatas e Naturais, Universidade Federal do Pará, Rua Augusto Corrêa 01, Guamá, 66075-970 Belém-PA, Brazil

${ }^{b}$ Centro de Pesquisa Agroflorestal da Amazônia Oriental-CPATU, CP 48, 66095-100 Belém-PA, Brazil

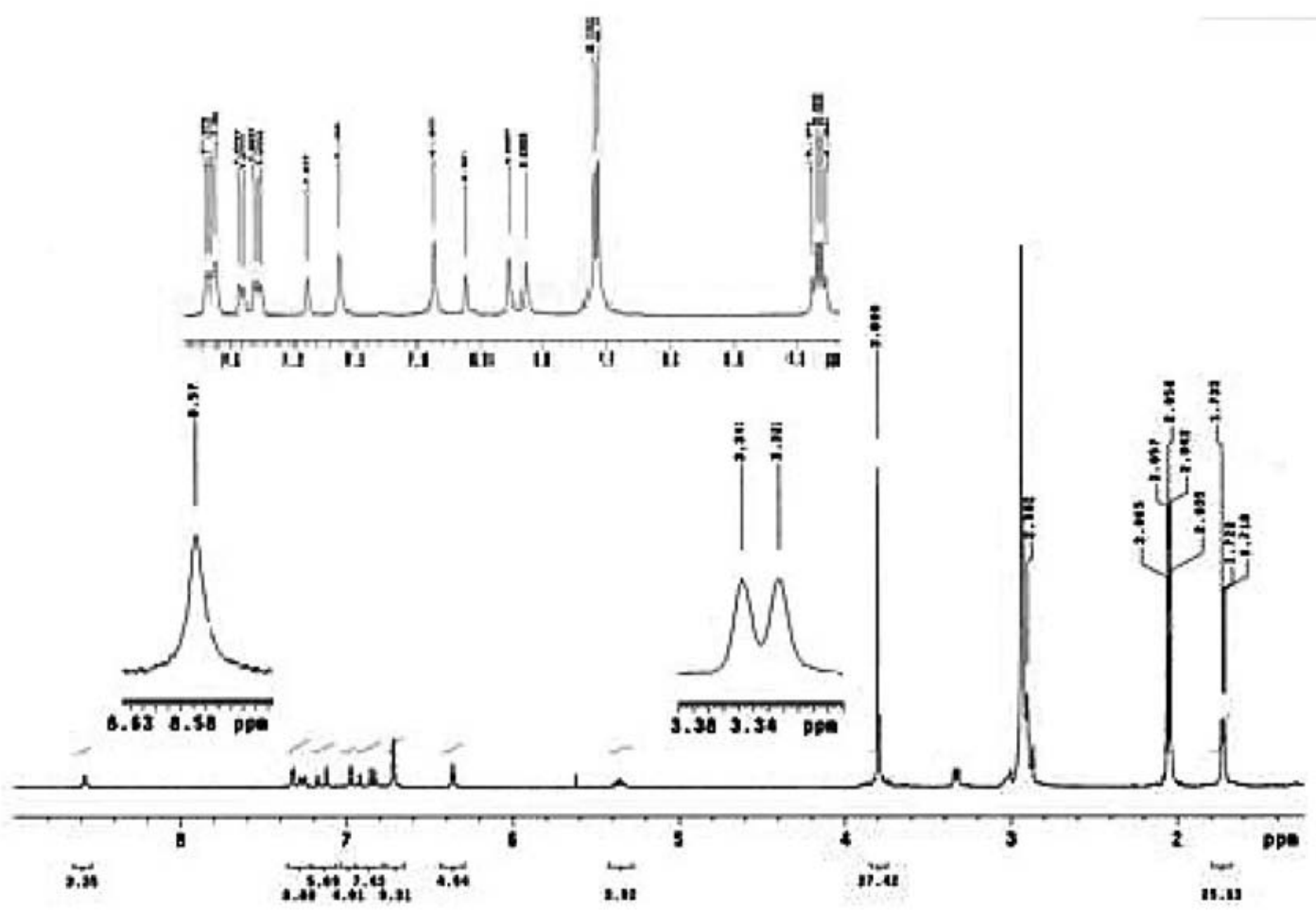

Figure S1. ${ }^{1} \mathrm{H}$ NMR spectrum [in $\left(\mathrm{CD}_{3}\right)_{2} \mathrm{CO}, 300 \mathrm{MHz}$ ] of the compound 2 isolated from leaves of Deguelia rufescens var. urucu. 


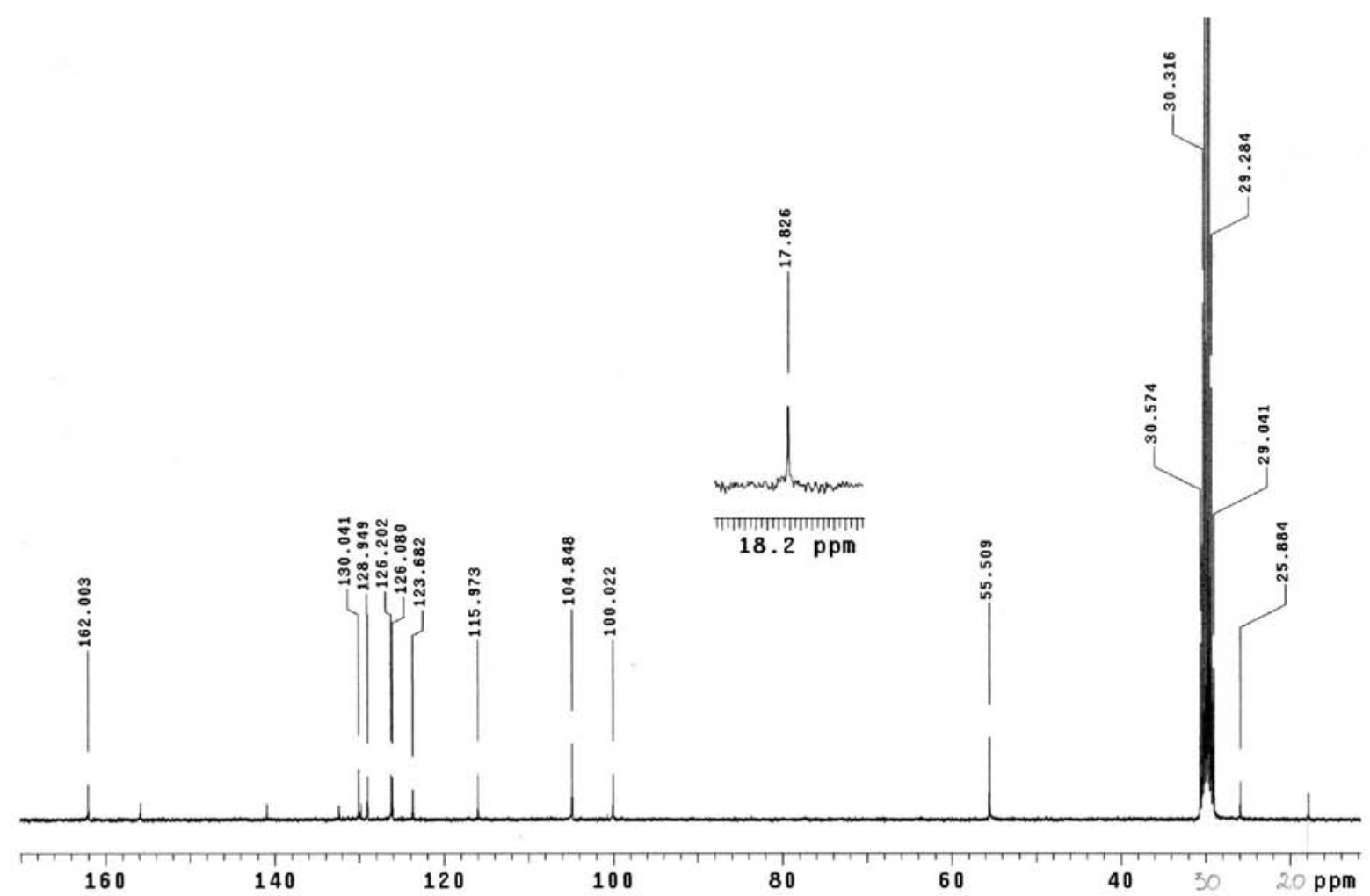

Figure $\mathbf{S 2} .{ }^{13} \mathrm{C}$ NMR spectrum [in $\left(\mathrm{CD}_{3}\right)_{2} \mathrm{CO}, 75 \mathrm{MHz}$ ] of the compound $\mathbf{2}$ isolated from leaves of Deguelia rufescens var. urucu.

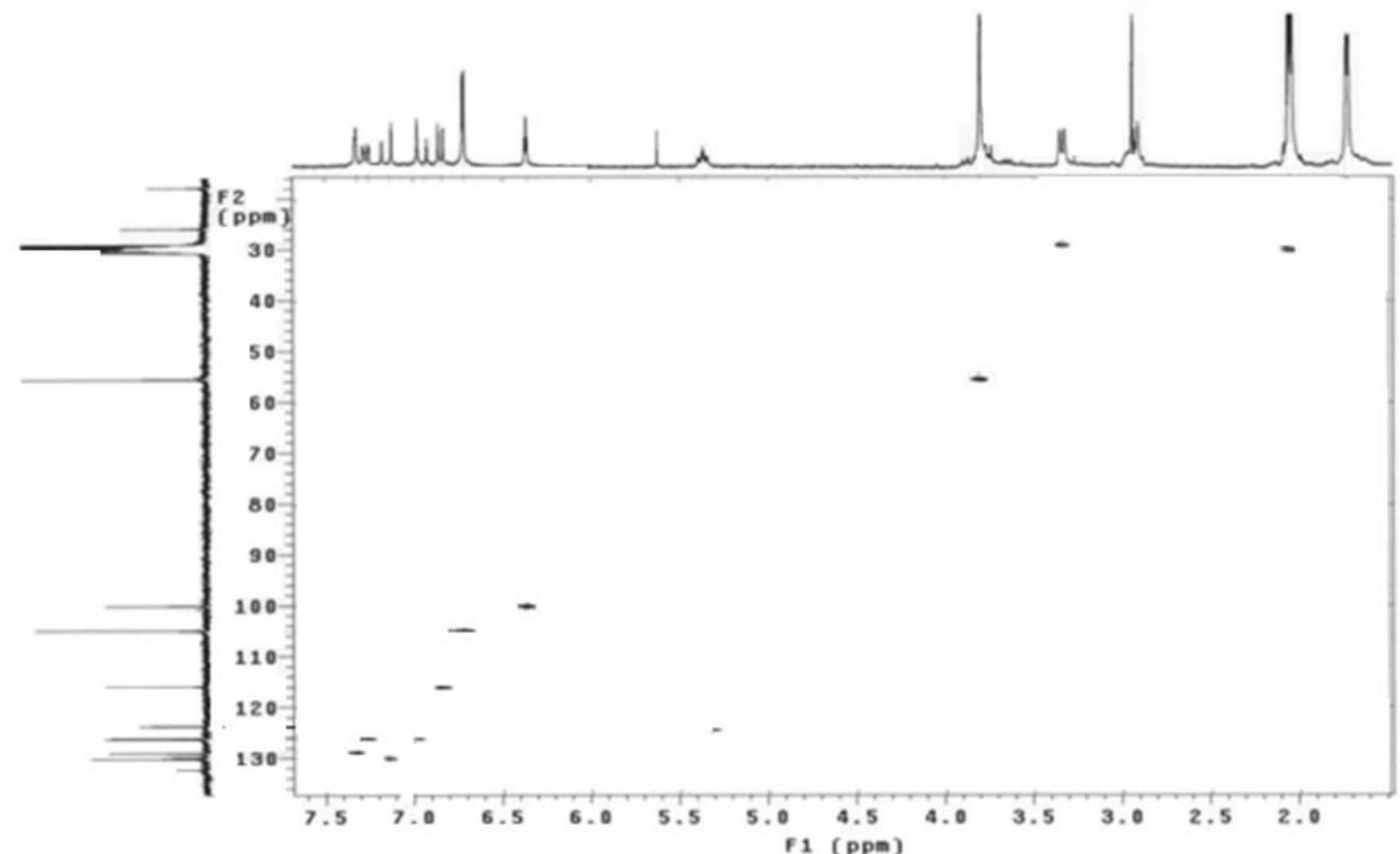

Figure S3. HETCOR NMR experiment [in $\left(\mathrm{CD}_{3}\right)_{2} \mathrm{CO}, 300 \times 75 \mathrm{MHz}$ ] of the compound 2 isolated from leaves of Deguelia rufescens var. urucu. 


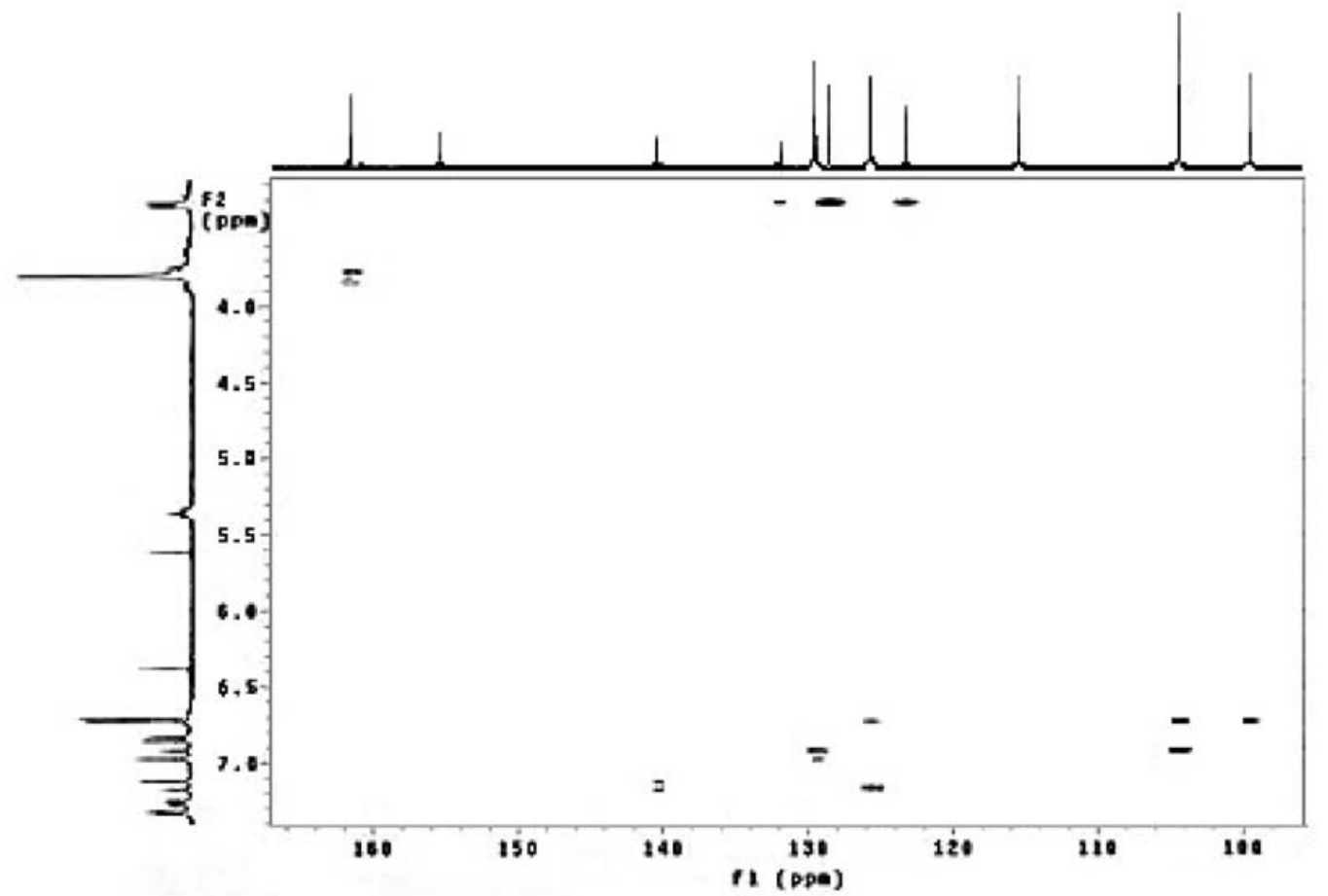

Figure S4. HMBC NMR experiment [in $\left.\left(\mathrm{CD}_{3}\right)_{2} \mathrm{CO}, 300 \times 75 \mathrm{MHz}\right]$ of the compound 2 isolated from leaves of Deguelia rufescens var. urucu.

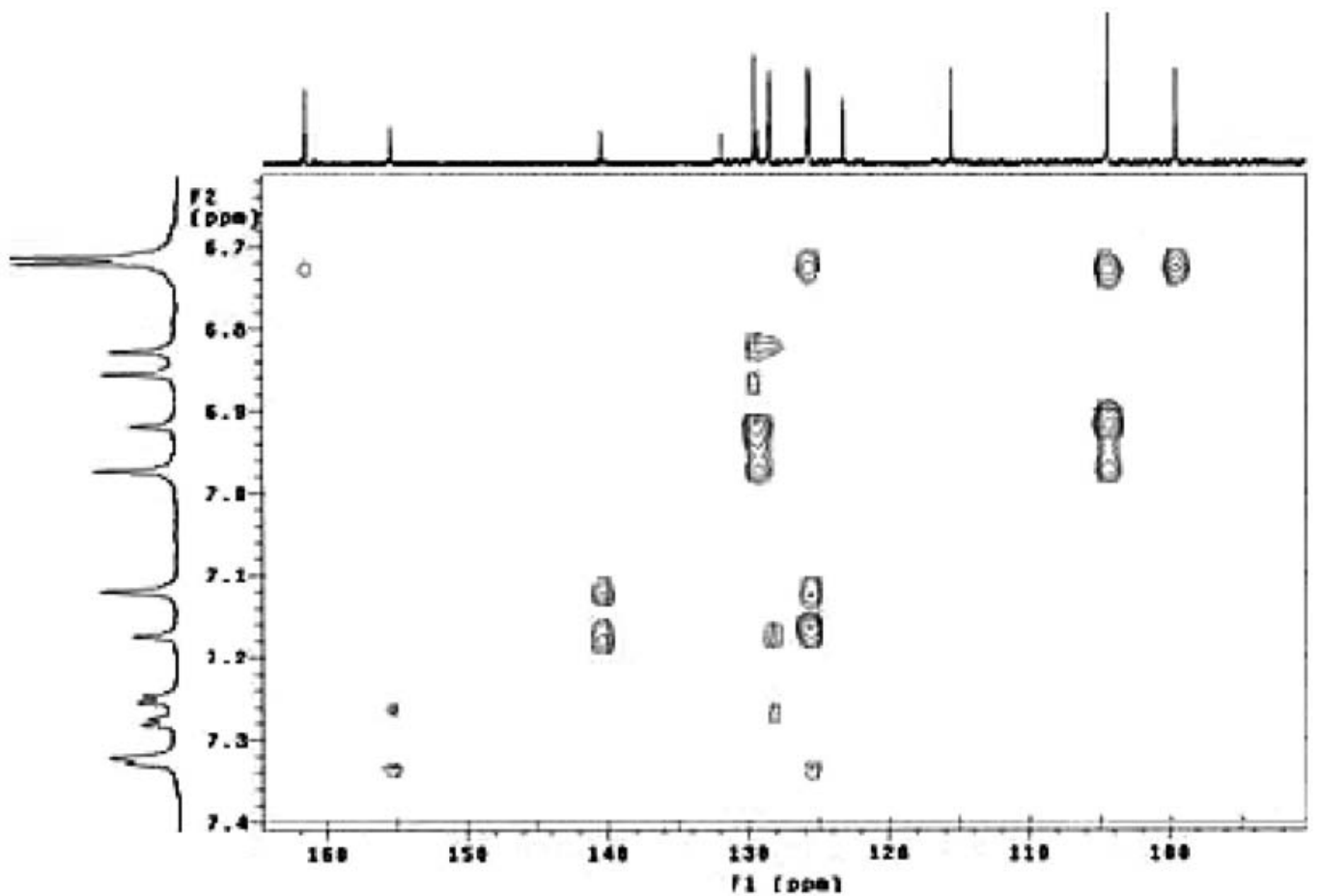

Figure S5. HMBC NMR experiment of the compound 2 (expansion 1). 


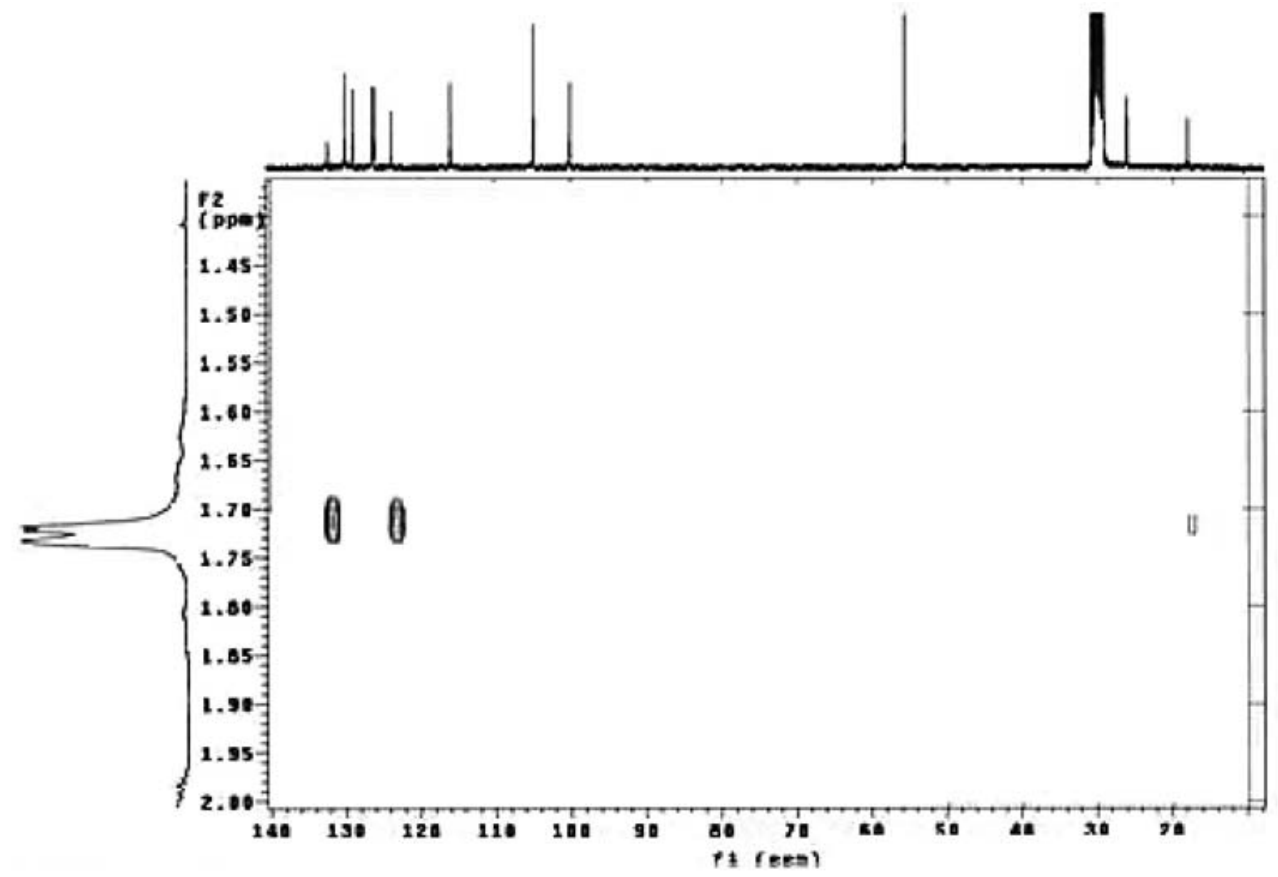

Figure S6. HMBC NMR experiment of the compound 2 (expansion 2).

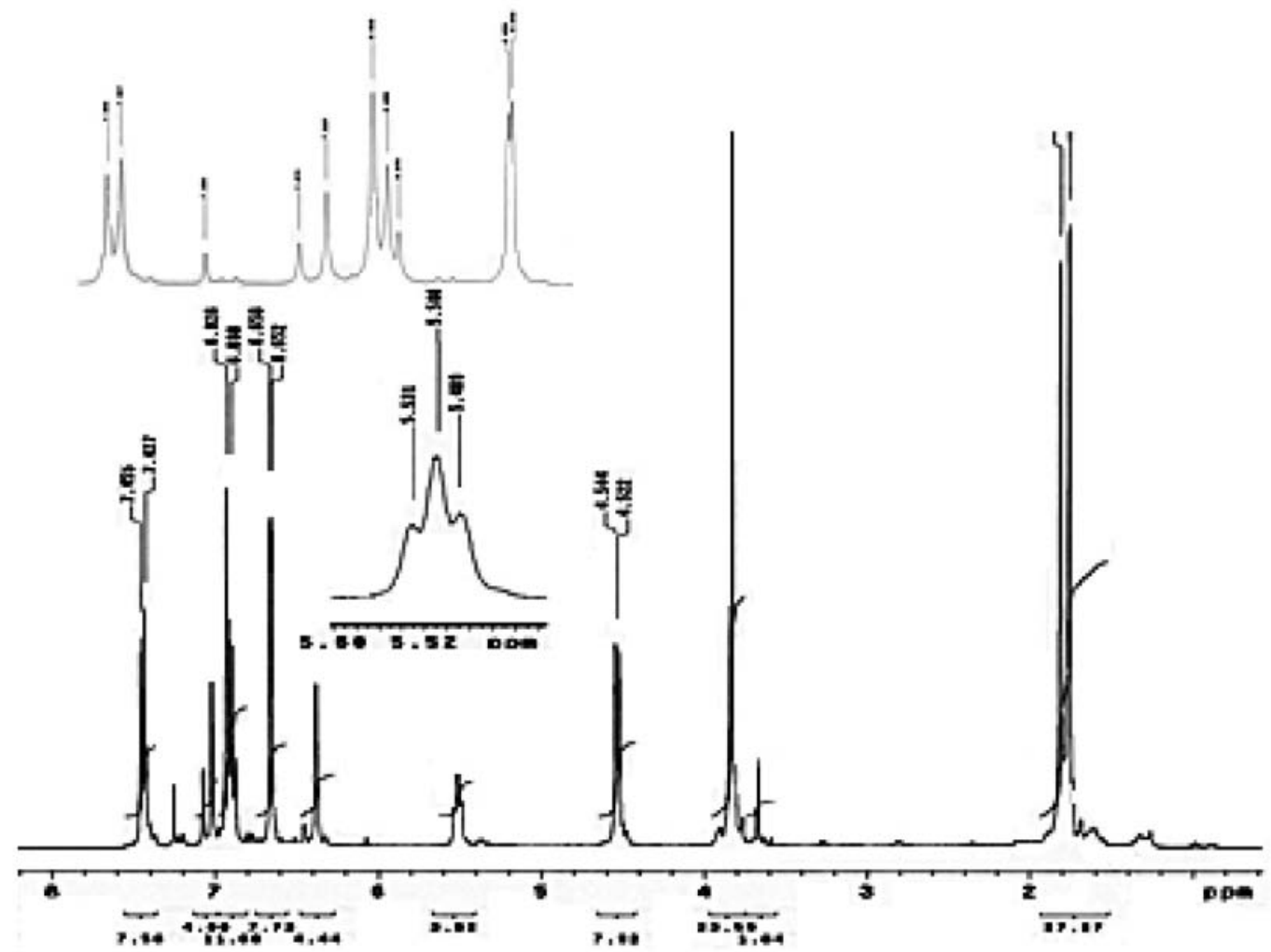

Figure S7. 'H NMR spectrum (in $\mathrm{CDCl}_{3}, 300 \mathrm{MHz}$ ) of the compound 4 isolated from leaves of Deguelia rufescens var. urucu. 


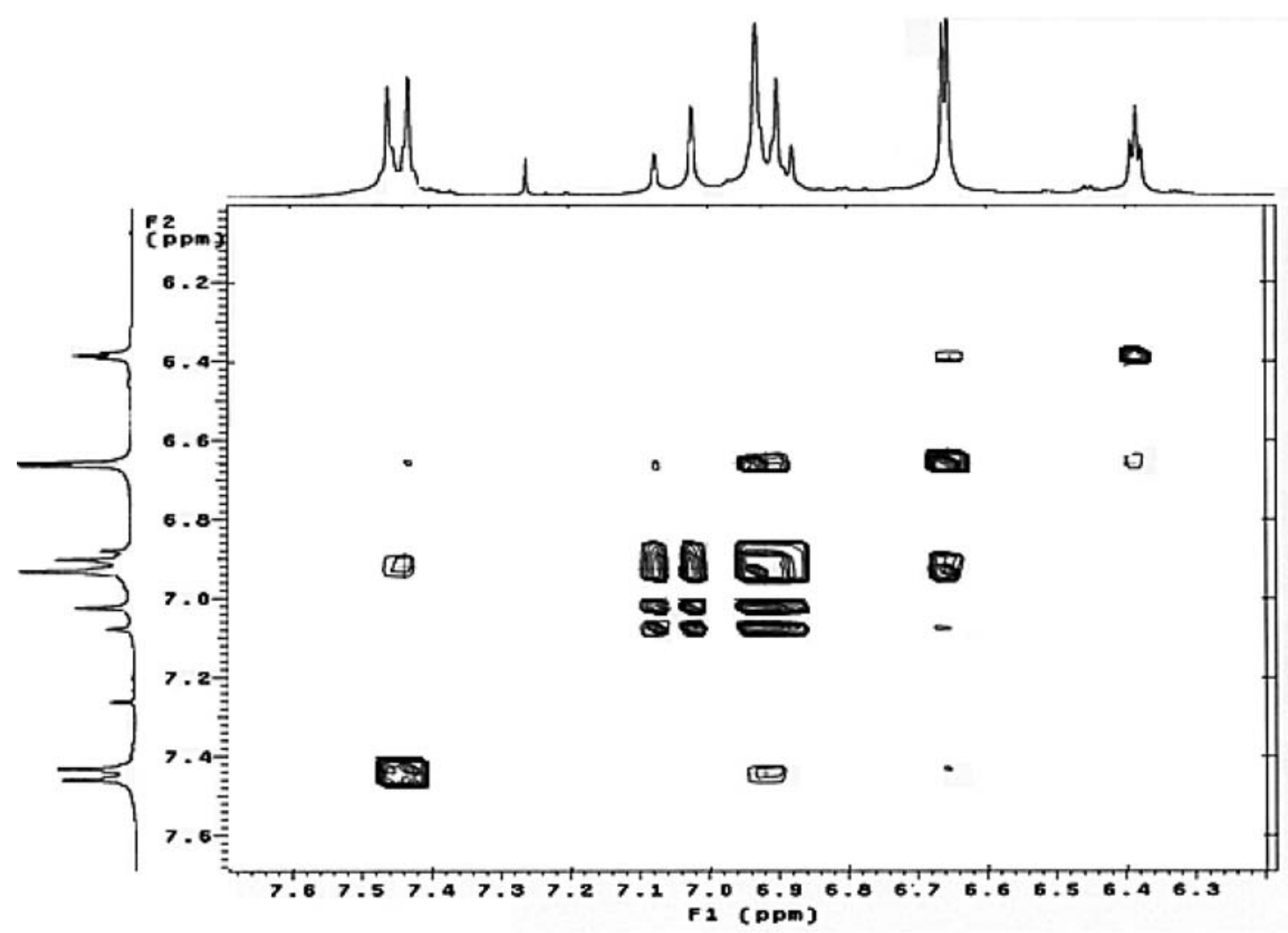

Figure S8. COSY ${ }^{1} \mathrm{Hx}^{1} \mathrm{HNMR}$ experiment (in $\mathrm{CDCl}_{3}, 300 \mathrm{MHz}$ ) of the compound $\mathbf{4}$ isolated from leaves of Deguelia rufescens var. urucu.

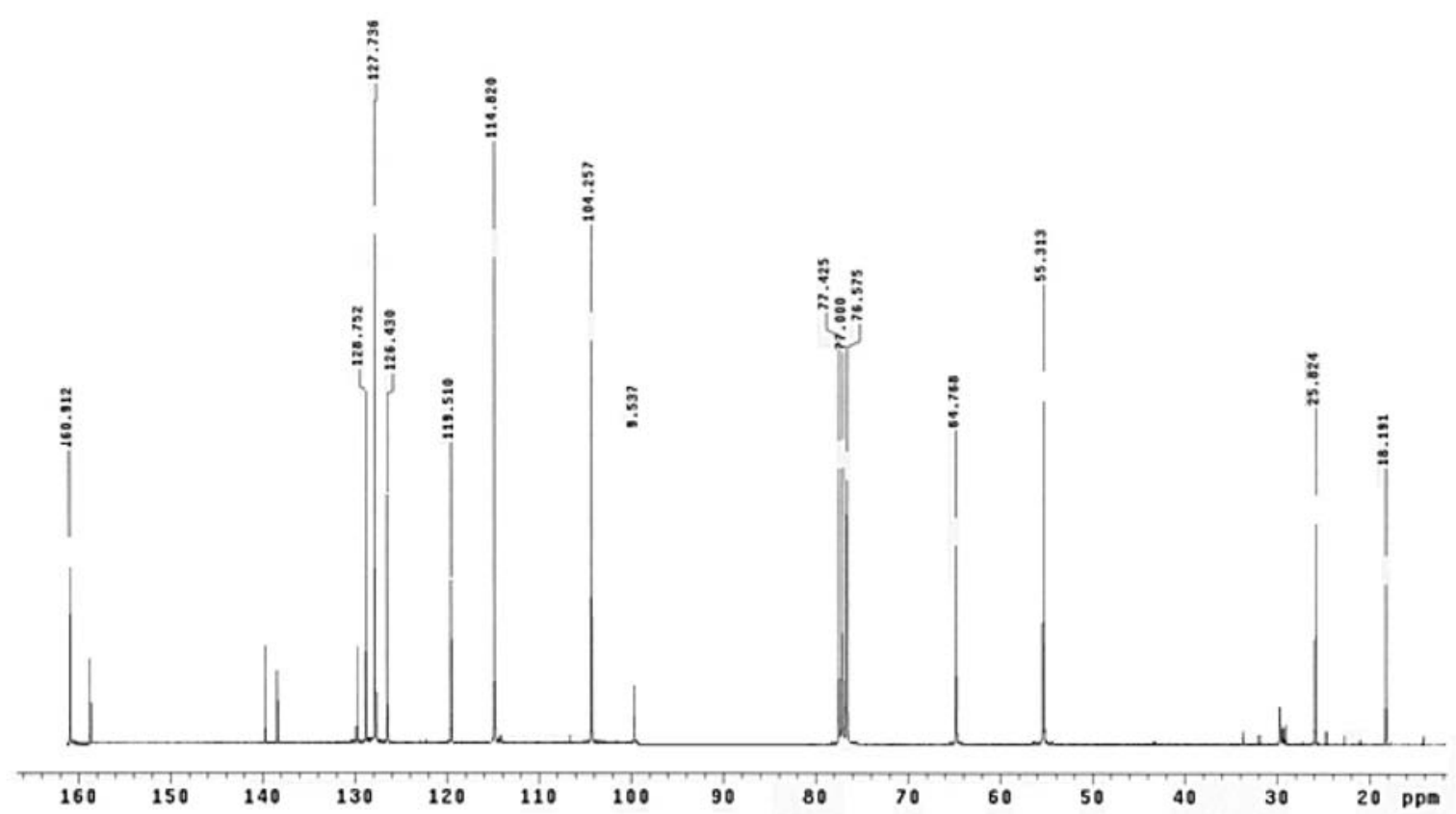

Figure S9. ${ }^{13} \mathrm{C}$ NMR spectrum (in $\mathrm{CDCl}_{3}, 75 \mathrm{MHz}$ ) of the compound 4 isolated from leaves of Deguelia rufescens var. urucu. 


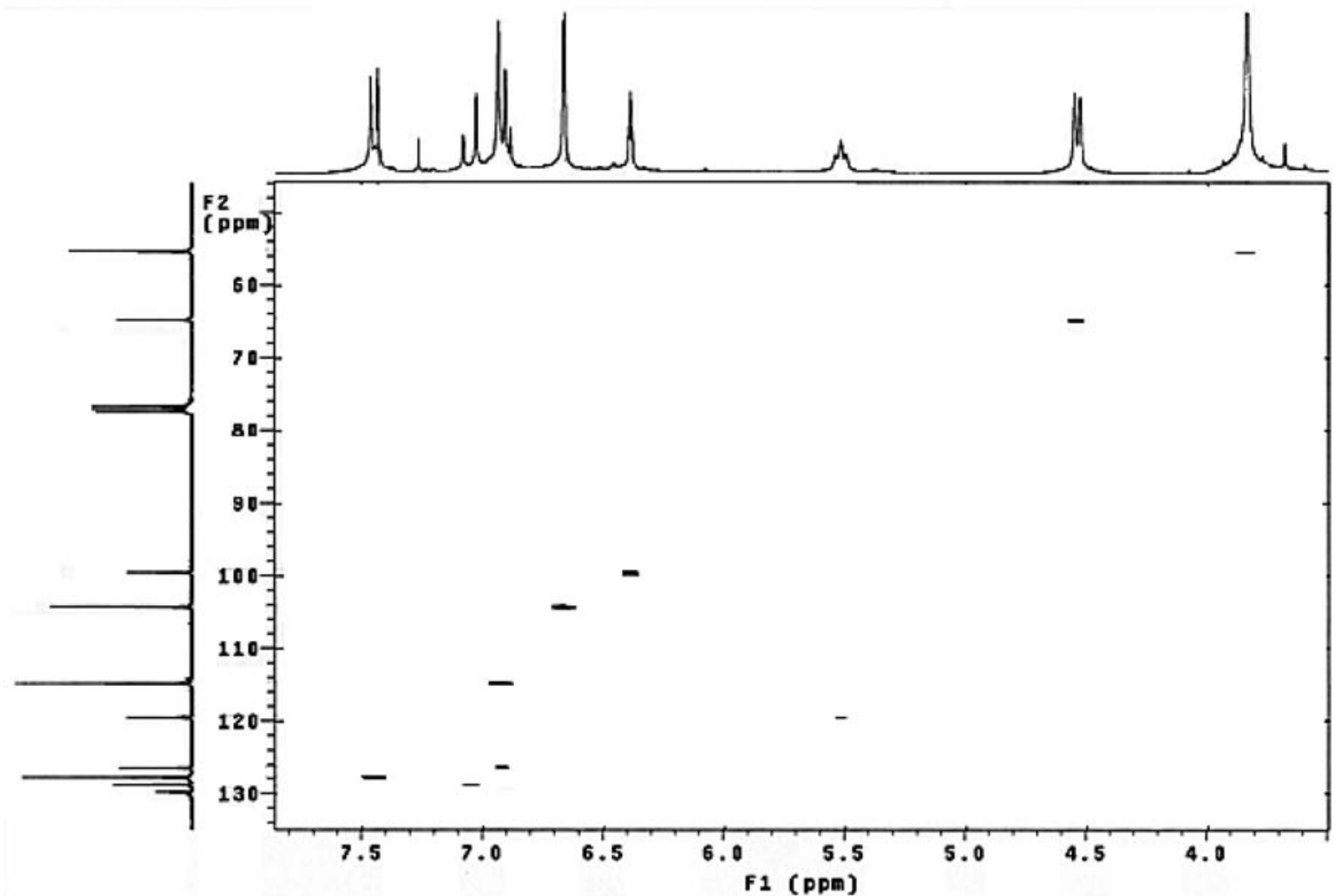

Figure S10. HETCOR NMR experiment (in $\mathrm{CDCl}_{3}, 300 \times 75 \mathrm{MHz}$ ) of the compound 4 isolated from leaves of Deguelia rufescens var. urucu.

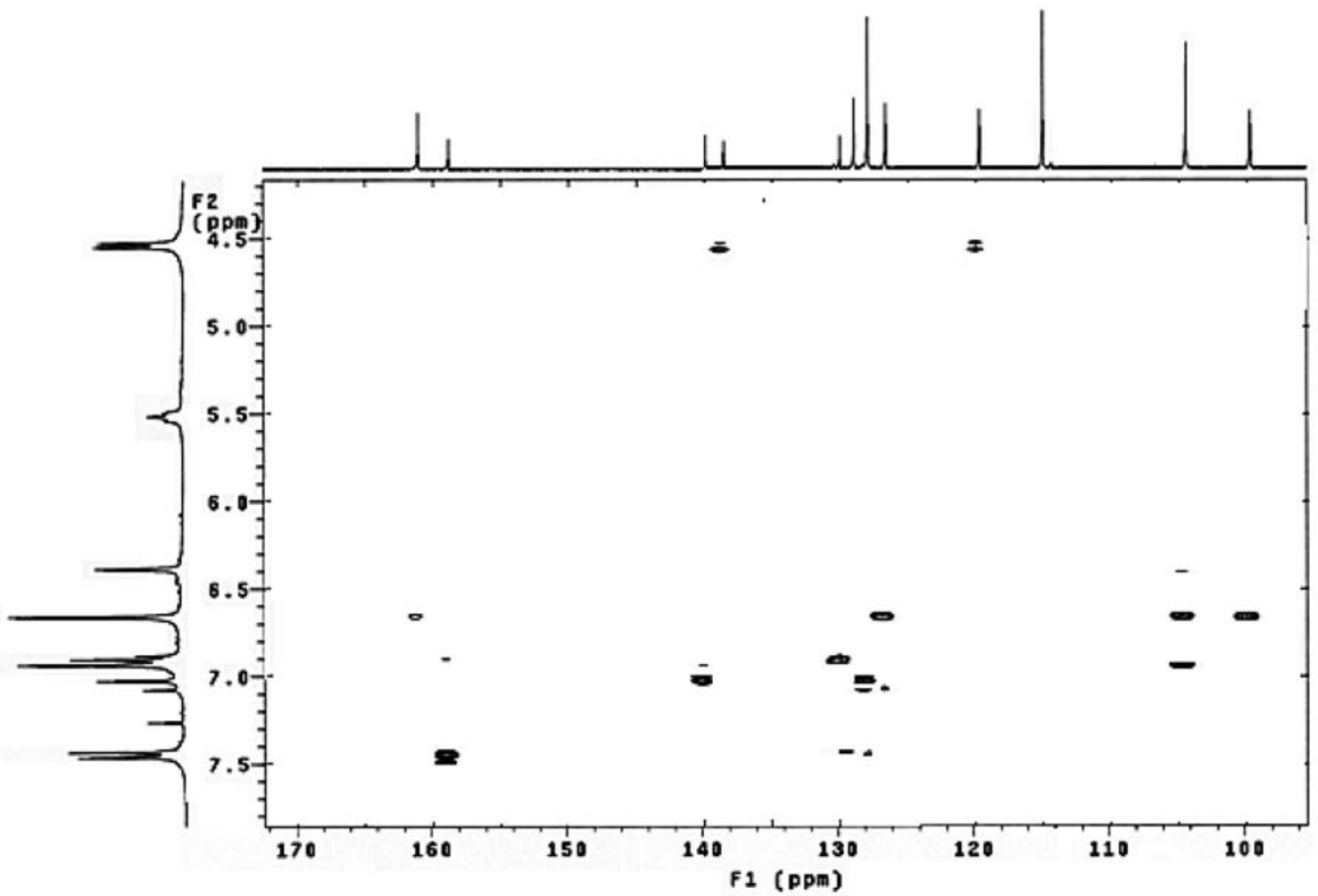

Figure S11. HMBC NMR experiment (in $\mathrm{CDCl}_{3}, 300 \times 75 \mathrm{MHz}$ ) of the compound 4 isolated from leaves of Deguelia rufescens var. urucu. 


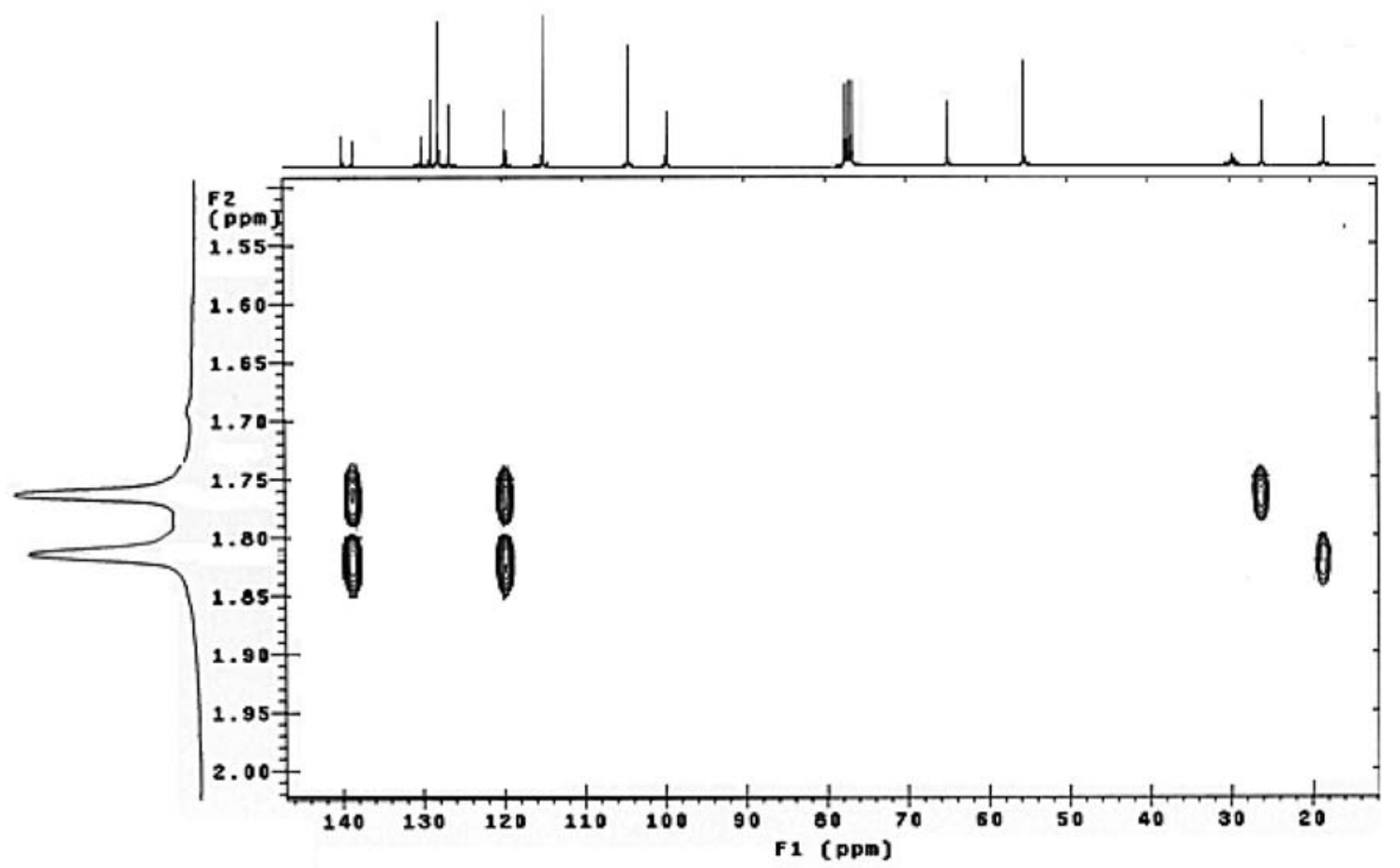

Figure S12. HMBC NMR experiment of the compound 4 (expansion 1).

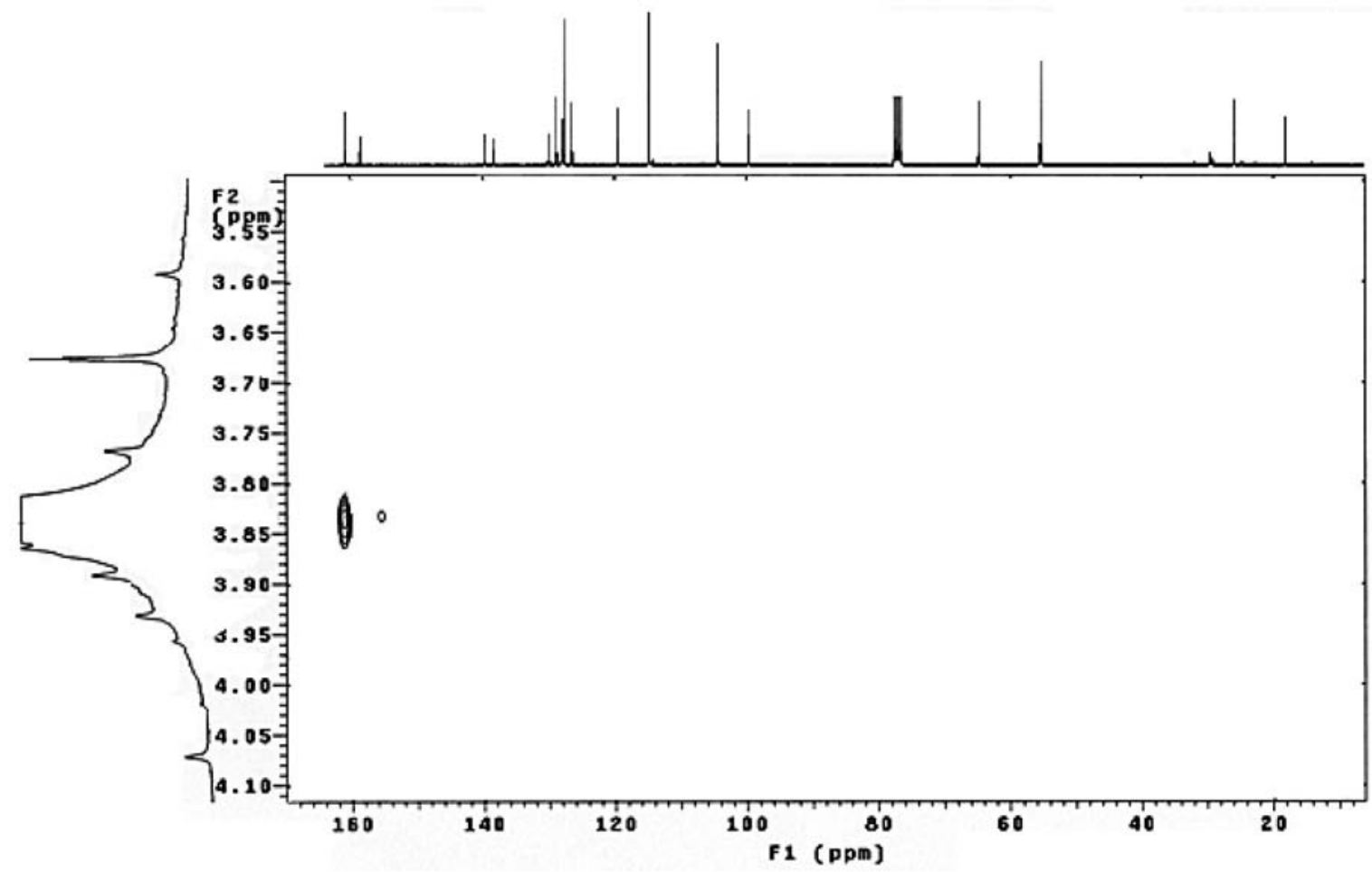

Figure S13. HMBC NMR experiment of the compound 4 (expansion 2). 